University of Nebraska - Lincoln

DigitalCommons@University of Nebraska - Lincoln

\title{
Limnological and Climatic Environments at Upper Klamath Lake, Oregon During the Past 45000 Years
}

\author{
J. Platt Bradbury \\ 5784 Horseradish Gulch, Golden, C0 80403, USA \\ Steven M. Colman \\ US Geological Survey, 384 Woods Hole Road, Woods Hole, MA 02543-1598, USA \\ Walter E. Dean \\ U.S. Geological Survey, Denver, CO, dean@usgs.gov
}

Follow this and additional works at: https://digitalcommons.unl.edu/usgsstaffpub

Part of the Earth Sciences Commons

Bradbury, J. Platt; Colman, Steven M.; and Dean, Walter E., "Limnological and Climatic Environments at Upper Klamath Lake, Oregon During the Past 45000 Years" (2004). USGS Staff -- Published Research. 310.

https://digitalcommons.unl.edu/usgsstaffpub/310

This Article is brought to you for free and open access by the US Geological Survey at DigitalCommons@University of Nebraska - Lincoln. It has been accepted for inclusion in USGS Staff -- Published Research by an authorized administrator of DigitalCommons@University of Nebraska - Lincoln. 


\title{
Limnological and climatic environments at Upper Klamath Lake, Oregon during the past 45000 years $^{\star}$
}

\author{
J. Platt Bradbury ${ }^{1}$, Steven M. Colman ${ }^{2 * *}$ and Walter E. Dean ${ }^{3}$ \\ ${ }^{1} 5784$ Horseradish Gulch, Golden, CO 80403, USA; ${ }^{2}$ US Geological Survey, 384 Woods Hole Road, \\ Woods Hole, MA 02543-1598, USA; ${ }^{3}$ US Geological Survey, Box 25046, MS 980, Denver, CO 80225, \\ USA;*Author for correspondence (e-mail: scolman@usgs.gov)
}

Received 20 November 2002; accepted in revised form 2 August 2003

Key words: Diatoms, Paleoclimate, Paleolimnology, Sediment geochemistry, Upper Klamath Lake

\begin{abstract}
Upper Klamath Lake, in south-central Oregon, contains long sediment records with well-preserved diatoms and lithological variations that reflect climate-induced limnological changes. These sediment archives complement and extend high resolution terrestrial records along a north-south transect that includes areas influenced by the Aleutian Low and Subtropical High, which control both marine and continental climates in the western United States. The longest and oldest core collected in this study came from the southwest margin of the lake at Caledonia Marsh, and was dated by radiocarbon and tephrochronology to an age of about $45 \mathrm{ka}$. Paleolimnological interpretations of this core, based upon geochemical and diatom analyses, have been augmented by data from a short core collected from open water environments at nearby Howards Bay and from a 9-m core extending to $15 \mathrm{ka}$ raised from the center of the northwestern part of Upper Klamath Lake. Pre- and full-glacial intervals of the Caledonia Marsh core are characterized and dominated by lithic detrital material. Planktic diatom taxa characteristic of cold-water habitats (Aulacoseira subarctica and $A$. islandica) alternate with warm-water planktic diatoms ( $A$. ambigua) between 45 and $23 \mathrm{ka}$, documenting climate changes at millennial scales during oxygen isotope stage (OIS) 3 . The full-glacial interval contains mostly cold-water planktic, benthic, and reworked Pliocene lacustrine diatoms (from the surrounding Yonna Formation) that document shallow water conditions in a cold, windy environment. After $15 \mathrm{ka}$, diatom productivity increased. Organic carbon and biogenic silica became significant sediment components and diatoms that live in the lake today, indicative of warm, eutrophic water, became prominent. Lake levels fell during the mid-Holocene and marsh environments extended over the core site. This interval is characterized by high levels of organic carbon from emergent aquatic vegetation (Scirpus) and by the Mazama ash $(7.55 \mathrm{ka})$, generated by the eruption that created nearby Crater Lake. For a brief time the ash increased the salinity of Upper Klamath Lake. High concentrations of molybdenum, arsenic, and vanadium indicate that Caledonia Marsh was anoxic from about 7 to $5 \mathrm{ka}$. After the mid-Holocene, shallow, but open-water environments returned to the core site. The sediments became dominated $(>80 \%)$ by biogenic silica. The open-water cores show analogous but less extreme limnological and climatic changes more typical of mid-lake environments. Millennial-scale lake and climate changes during OIS 3 at Upper Klamath Lake contrast with a similar record of variation at Owens Lake, about $750 \mathrm{~km}$ south. When Upper Klamath Lake experienced cold-climate episodes during OIS 3, Owens Lake had warm but wet episodes; the

\footnotetext{
^ This is the fourth in a series of eight papers published in this special issue, resulting from paleoenvironmental studies in the Upper Klamath Lake Basin. These studies were conducted by the US Geological Survey and its collaborators as part of a research effort called the Correlation of Marine and Terrestrial Records Project. Steven M. Colman served as guest editor of this special issue.
} 
reverse occurred during warmer intervals at Upper Klamath Lake. Such climatic alternations apparently reflect the variable position and strength of the Aleutian Low during the mid-Wisconsin.

\section{Introduction}

Long lacustrine records in fault-controlled basins in south-central Oregon and in northern California contain abundant diatoms and pollen that record past climatic and limnological fluctuations in this region. One record, Tule Lake in northern California (location: Colman et al. 2004b - this issue, Figure 1), extends to $3 \mathrm{Ma}$ and provides an unequaled chronicle of climate change from the late Pliocene to the Holocene for this part of the world (Bradbury 1991). Tule Lake, however, even before artificial drainage, was an extensive, shallow basin and subject to desiccation and very slow deposition rates during arid climate intervals. Consequently, the continuity of the Tule Lake record is compromised for high resolution paleolimnological and paleoclimatic analysis. The same problem exists for many other now-dry basins in the Klamath region (Adam et al. 1995). Cores raised from extant lakes can link modern limnological and climatic environments to past environments and provide continuous, high-resolution records of limnological, floral, and climatic change. Upper Klamath Lake provides an appropriate setting for preservation of long, high-resolution, lacustrine records because of its generally high productivity, large size, and open drainage.

Sediment cores from Upper Klamath Lake (see Colman et al. 2004b - this issue), dated by radiocarbon and tephrochronology (Colman et al. 2004a - this issue), extend to about $45 \mathrm{ka}$. These cores document limnological and climatic changes that not only characterized the Holocene, but also the late and full glacial as well as the preceding, rapidly varying, climate regimes of the last interstadial (oxygen isotope stage 3; OIS 3). High resolution documentation of climatic changes within this time frame can reveal much about the rapidity of major shifts in climate modes that have major impacts on terrestrial environments. For example, comparison with the paleolimnological record from Owens Lake, covering the same time interval as the Caledonia Marsh core, allows an evaluation of terrestrial climate changes at different latitudes in western North America east of the Sierra Nevada and Cascade mountain ranges.

\section{Methods}

The lacustrine and marsh sediment cores discussed here (CM2, HB, and $\mathrm{K} 1)$, as well as the methods used to obtain them, are described by Colman et al. (2004b - this issue). Diatoms were prepared at $5-\mathrm{cm}$ (CM2 and HB) or 10-cm (K1) intervals by chemical oxidation of $0.5 \mathrm{ml}$ wet samples with $100{ }^{\circ} \mathrm{C}$, concentrated nitric acid, and rinsed in distilled water. Equal volume aliquots were settled on coverslips (Battarbee 1973) and mounted in naphrax (refractive index $=1.6$ ). Four hundred (minimum) valves counted per sample established relative percentages of the dominant diatom species in the cores.

Splits of selected samples were analyzed for concentrations of total carbon (TC) by coulometric titration of $\mathrm{CO}_{2}$ extracted from the sediment by combustion at $950{ }^{\circ} \mathrm{C}$ (Engleman et al. 1985). Thirty-four samples were analyzed for inorganic carbon by acidification, and all had $<0.01 \%$ inorganic carbon by weight, confirming the lack of carbonate minerals in Upper Klamath Lake sediments. Therefore, percent TC can be taken as a measure of total organic carbon (TOC). Selected samples were also analyzed for 30 major, minor, and trace elements from a multi-acid digestion by inductively coupled, argon-plasma emission spectrometry (Lichte et al. 1987). Only results for $\mathrm{Al}, \mathrm{Ti}, \mathrm{Fe}, \mathrm{Mo}, \mathrm{As}$, and $\mathrm{V}$ will be discussed in this paper: $\mathrm{Al}, \mathrm{Ti}$, and $\mathrm{Fe}$, as measures of the detrital aluminosilicate fraction, and Mo, As, and V, as indicators of anoxia.

Radiocarbon ages and tephrochronology provide the chronological control for the cores. The methodology and data interpretations that result in the age models for the Upper Klamath Lake records are discussed in Colman et al. (2004a this issue). For core CM2, a weighted curve fitted through the calendar-age equivalents of the radiocarbon and tephra ages (Figure 1) provides the age model for the diatom stratigraphy. Diatom correlations to a ${ }^{210} \mathrm{~Pb}$-dated short gravity core (core C-7, Colman et al. 2004b - this issue) and radiocarbon ages provide chronological control for core HB from Howard Bay. Diatom correlations, radiocarbon ages and the Mazama ash fix the chronology of core K1 (Colman et al. 2004a - this issue). 


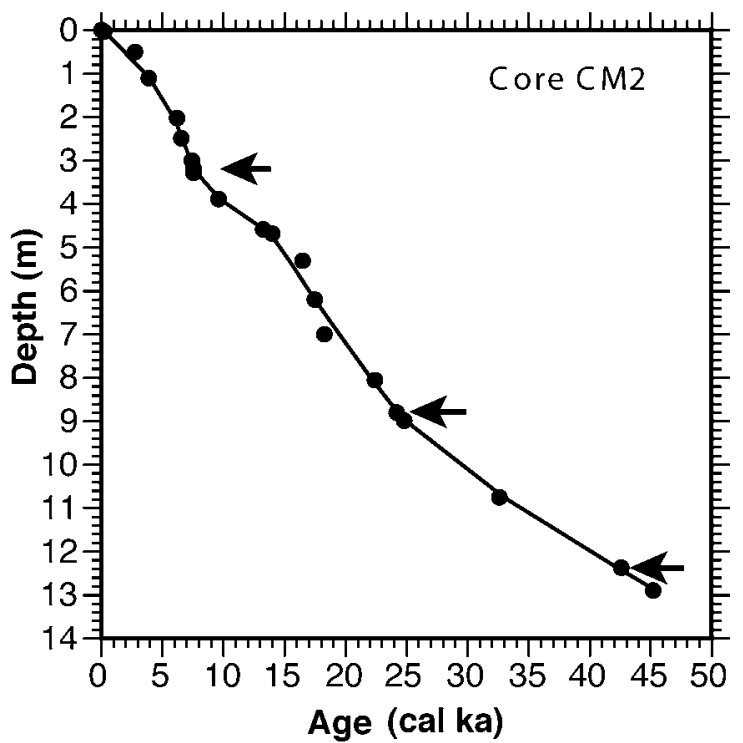

Figure 1. Age (in cal ka) versus depth in core for core CM2 (Colman et al. 2004a - this issue). The fitted 25\% weighted curve describes the age-depth relations used for the stratigraphy of that core. Arrowheads mark location of tephra data points; all other points are radiocarbon ages.

Ages in this paper are expressed in thousands of calibrated years BP $(\mathrm{ka})$ unless otherwise indicated.

\section{Stratigraphy and interpretation of core CM2}

The 12.8-m Caledonia Marsh core (CM2) extends to an estimated age of about $45 \mathrm{ka}$ based on the presence of the Olema tephra near the base of the core (Colman et al. 2004a - this issue) (Figure 1). The high concentrations of $\mathrm{Al}, \mathrm{Ti}$, and $\mathrm{Fe}$ in the sediments deposited prior to $15 \mathrm{ka}$ (Figure 2a) indicate that the sediment is composed largely of inorganic detrital volcanoclastic material. The highest $\mathrm{Al}$ concentration $(9.5 \%)$ is greater than the Medicine Lake Volcanics (8.8\%) and volcanic ash in Tule Lake $(8.7 \%)$ just south of Upper Klamath Lake in northern California (Dean 1996). Assuming that $9.5 \% \mathrm{Al}$ is a representative concentration of $\mathrm{Al}$ in the detrital (lithogenic) material entering Upper Klamath Lake, then the percent detrital fraction in any sample can be calculated based on the $\mathrm{Al}$ concentration in that sample (Figure 2a). Rosenbaum and Reynolds (2004 this issue) made a similar calculation using Ti based on the assumption that the biogenic-free lithic component of sediments in Upper Klamath Lake contained $0.593 \% \mathrm{Ti}$. The percentages of detrital material based on the Ti data of Rosenbaum and Reynolds (2004 - this issue) are plotted in Figure $2 \mathrm{a}$ along with our values based on $\mathrm{Al}$ for comparison. The two methods of calculating percent total detrital material are in excellent agreement. The percentage of total biogenic material (essentially organic matter plus biogenic silica) was calculated by Rosenbaum and Reynolds (2004 - this issue, their Figure 2) as 100 minus percent detrital material. Peaty marsh sediments deposited between 7.5 and $5 \mathrm{ka}$ are composed of up to $48 \%$ TOC, but the weight percentage of total organic matter $(\mathrm{OM})$ is higher from combined $\mathrm{H}$ and $\mathrm{O}$ analyses. For Minnesota lake sediments, Dean (1974) and Dean and Schwalb (2002) demonstrated that the percentage of OM, as determined by loss on ignition (at $500{ }^{\circ} \mathrm{C}$ ), is twice the percentage of TOC. Assuming that this relation holds for Caledonia Marsh sediments, then the percentage of biogenic silica ( $\%$ BSi) can be calculated as:

$$
\begin{aligned}
\% \mathrm{BSi}= & 100 \%-[(\% \text { TOC } \times 2) \\
& +\% \text { detrital material }]
\end{aligned}
$$

Therefore, the sediments in Caledonia Marsh consist of three main components: detrital material, biogenic silica, and organic matter (Figure 2b). The sediments deposited between about 35 and $15 \mathrm{ka}$ consist of predominantly detrital material (volcanic rock debris); the sediments deposited between 7.5 and $5 \mathrm{ka}$ consist of predominantly organic matter (marsh-plant debris, mostly Scirpus); and the sediments deposited after $5 \mathrm{ka}$ are composed predominantly of biogenic silica (diatom debris). The sharp increase in lithophile elements at the top of the core (Figure 2a) reflects basaltic road metal used to construct the berm separating Caledonia Marsh from the open water of Howard Bay. During the time that the site was occupied by a marsh (7.5-5 ka), the sediments were anoxic as indicated by high concentrations of Mo, As, V, and organic matter (Dean 1993) (Figure 2b).

The diatom stratigraphy of CM2 (Figure 3a-e) documents paleolimnological changes for the past $45 \mathrm{ka}$ that reflect changes in the seasonality of nutrient fluxes under variable conditions of lake circulation, ice cover, and wind stress. Today, as in the past, Upper Klamath Lake overflows and cannot rise significantly above its spill level except 
a) Upper Klamath Lake, Oregon

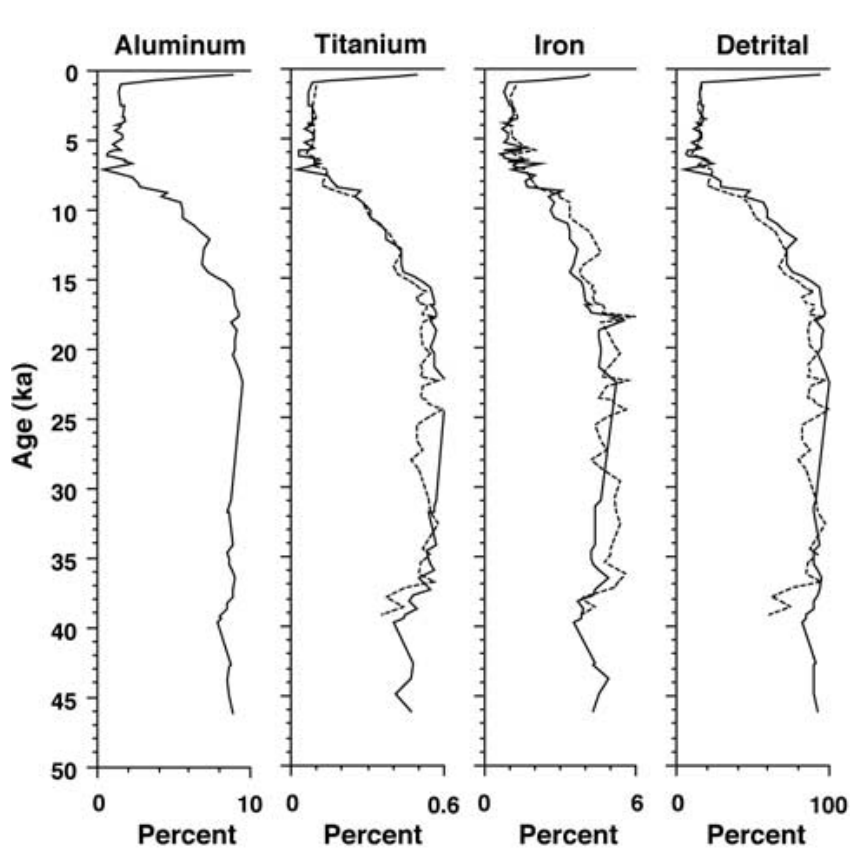

b) Upper Klamath Lake, Oregon Caledonia Marsh core CM2
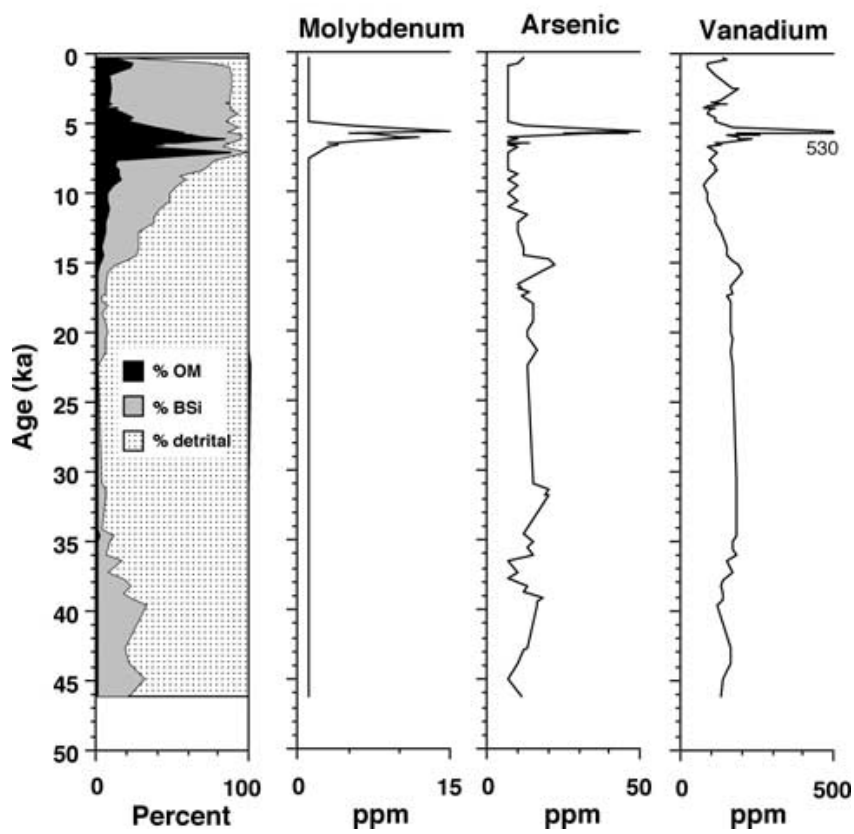

Figure 2. Geochemical analyses for core CM2 plotted against age (in cal ka). (a) Weight percent of aluminum, titanium, iron, and lithogenic detrital. Our values are plotted as solid lines; those of Rosenbaum and Reynolds (2004 - this issue) are plotted as dashed lines. (b) Weight percentages of total organic matter (OM), biogenic silica (BSi), and lithogenic detrital material, and concentrations (ppm) of molybdenum, arsenic, and vanadium. 
by tectonic elevation of its outlet. The lack of saline-water diatom species throughout cores from Upper Klamath Lake indicates that the lake did not fall below its outlet for any appreciable time in the past.

The base of core CM2 contains high percentages of Stephanodiscus niagarae, S. oregonicus, Synedra berolinensis, and Aulacoseira ambigua that collectively indicate chemical and eutrophic nutrient conditions comparable to Upper Klamath Lake before Euro-American discovery (Bradbury et al. 2004 this issue). Species of the 'Fragilaria' complex (principally including Staurosira construens, Staurosirella pinnata, and Pseudostaurosira brevistriata) were also elements of the $45-\mathrm{ka}$ diatom assemblage, but their modest percentages may suggest deeper water environments than exist today, possibly related to the progressive role of sedimentation in filling the lake basin. Between 45 and 40 ka, Staurosirella pinnata and Cyclostephanos sp. become common (Figure 3a), probably indicating increased subaquatic vegetation and expansion of littoral habitats as well as greater nutrient fluxes. Like most of the 'Fragilaria' complex, Staurosirella pinnata lives loosely attached to plant and mineral substrates in the photic zone, but may become planktic when there is sufficient turbulence $(=\mathrm{a}$ tychoplanktic habitat), whereas the Cyclostephanos sp. is similar to taxa of this genus that prefer highly eutrophic conditions (Stoermer et al. 1987).

Between 40 and $25 \mathrm{ka}$, the Upper Klamath Lake record in core CM2 is characterized by alternating millennial dominances of Aulacoseira ambigua and A. subarctica (Figure 3a). Aulacoseira subarctica blooms in many northern temperate and boreal lakes during the spring when low, but sufficient light becomes available for photosynthesis (Jewson 1992). This diatom has the ability to maintain a slowly expanding population on the bottom of shallow lakes after nutrient depletion has terminated the bloom, which provides an inoculum of the diatom to take advantage of the arrival of favorable conditions the following year (Jewson 1992). According to distribution studies, Aulacoseira ambigua blooms mostly during the summer months and is found in generally warmer and more eutrophic lacustrine systems than $A$. subarctica (Kilham et al. 1986). Growth of Aulacoseira ambigua during the summer suggests that this diatom requires abundant illumination to flourish, whereas the proliferation of $A$. subarctica in the early spring implies that it grows at much lower levels of light intensity.

Aulacoseira islandica and reworked Pliocene diatoms also provide paleoclimatic information for the $\mathrm{CM} 2$ record between 40 and $25 \mathrm{ka}$ (Figure 3a, b). Like Aulacoseira subarctica, A. islandica blooms in the cold, early spring of northern temperate and boreal lakes, sometimes under ice when light levels first begin to increase in the spring. The reworked Pliocene diatoms (mostly Aulacoseira paucistriata, A. solida, and Cyclotella elgeri) come from diatomaceous outcrops of the Yonna Formation commonly exposed east of Upper Klamath Lake (Bradbury 1991). The transportation of these Pliocene diatoms to the lake was probably by wind and seasonally energetic runoff via the Sprague River, which drains outcrops of the Yonna Formation. Collectively, these diatoms indicate that overall, the climate of Upper Klamath Lake during the final two-thirds of OIS $3(55-25 \mathrm{ka})$ was colder and windier than modern conditions in this region.

Nevertheless, the alternating dominance of Aulacoseira subarctica and A. ambigua indicates millennial-scale fluctuations of limnological conditions probably related to cooler and warmer climatic conditions, respectively. Rock-magnetic and geochemical proxies of glacial rock flour in the sediments correspond with the stratigraphic distribution of Aulacoseira subarctica (Reynolds et al. 2004 - this issue). This suggests that increased lake turbidity may have played a role in promoting the dominance of the low-light diatom, Aulacoseira subarctica, during times of colder climate and glacier expansion in the Upper Klamath Lake drainage.

These fluctuating climatic and limnological conditions persisted until after $25 \mathrm{ka}$ when increases in benthic diatoms (Navicula, Nitzschia, Amphora pediculus, and Rhoicosphenia curvata), Aulacoseira islandica, reworked Pliocene diatoms, and a terrestrial diatom species, Hantzschia amphioxys, dominate the record (Figure 3a, b). Fluctuations in Aulacoseira subarctica abundance continue until about $22 \mathrm{ka}$. These stratigraphic changes document the character of Upper Klamath Lake during the full glacial period (OIS 2). The lake became shallower, more wind-swept and turbid. The earlier, millennial-scale variability had disappeared by $21 \mathrm{ka}$, but the cold and probably somewhat arid conditions lasted until $15 \mathrm{ka}$. 


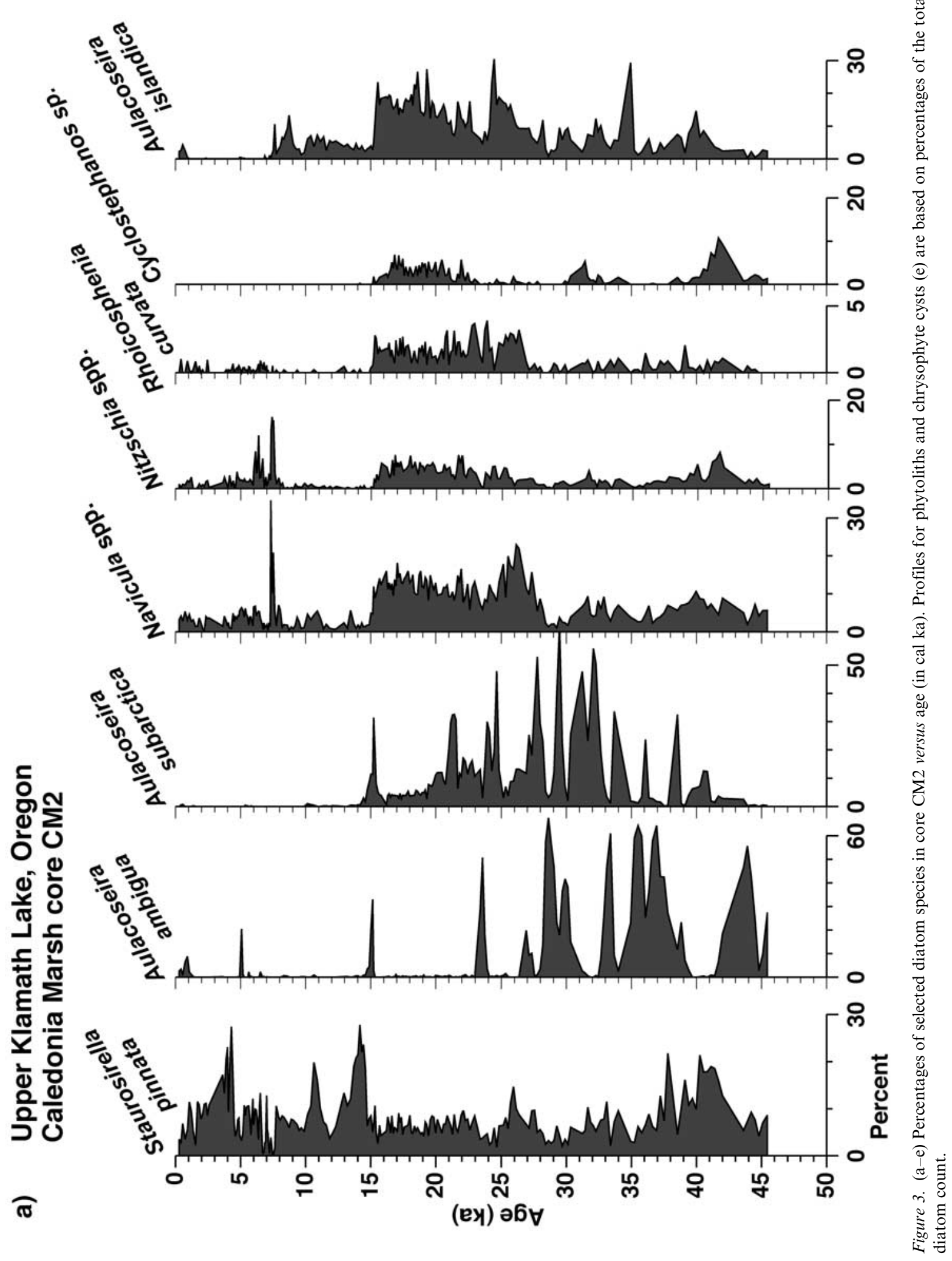



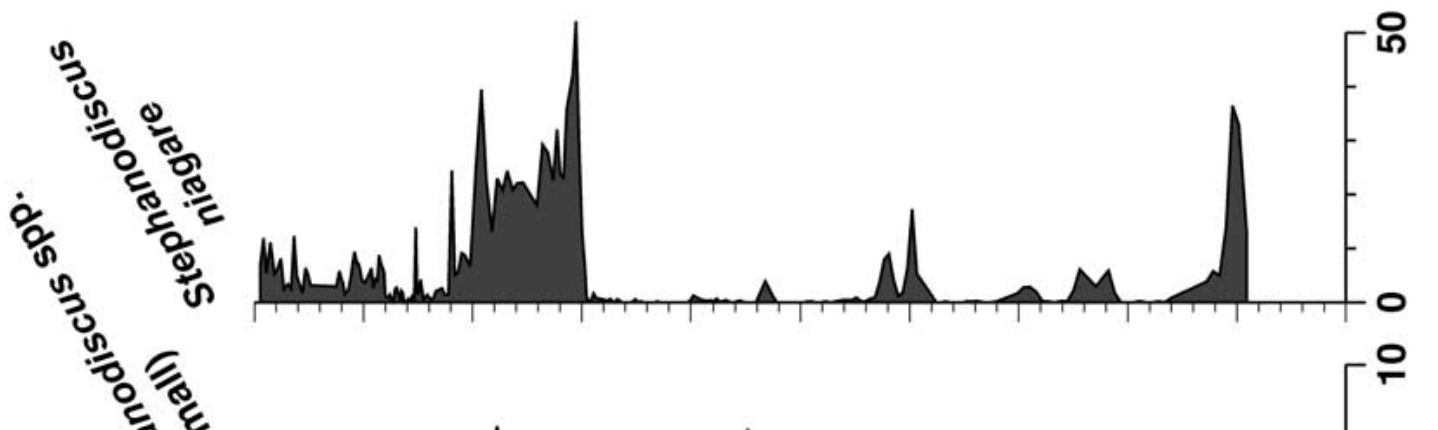

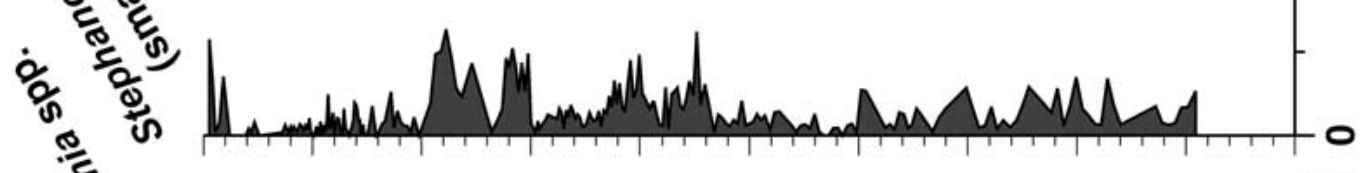
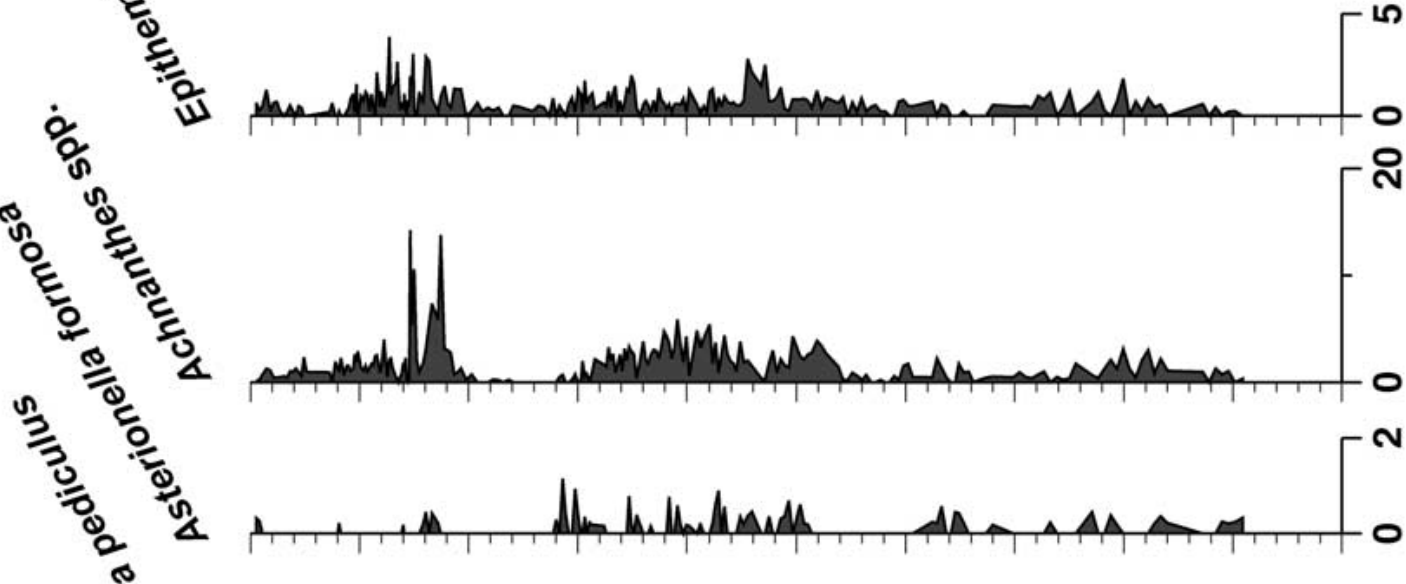

ह

立

\%

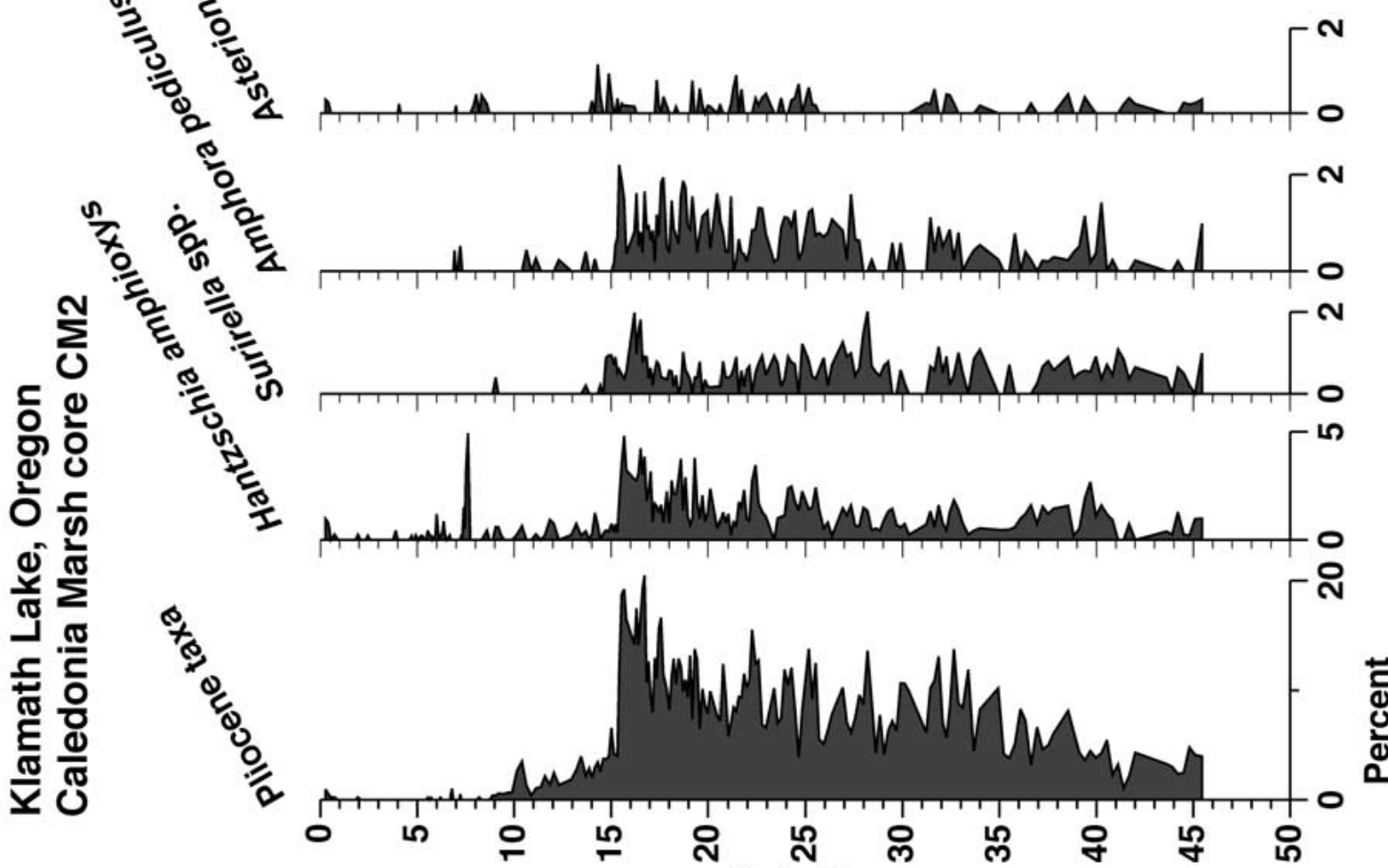

突

으 (घ) ә6ु 


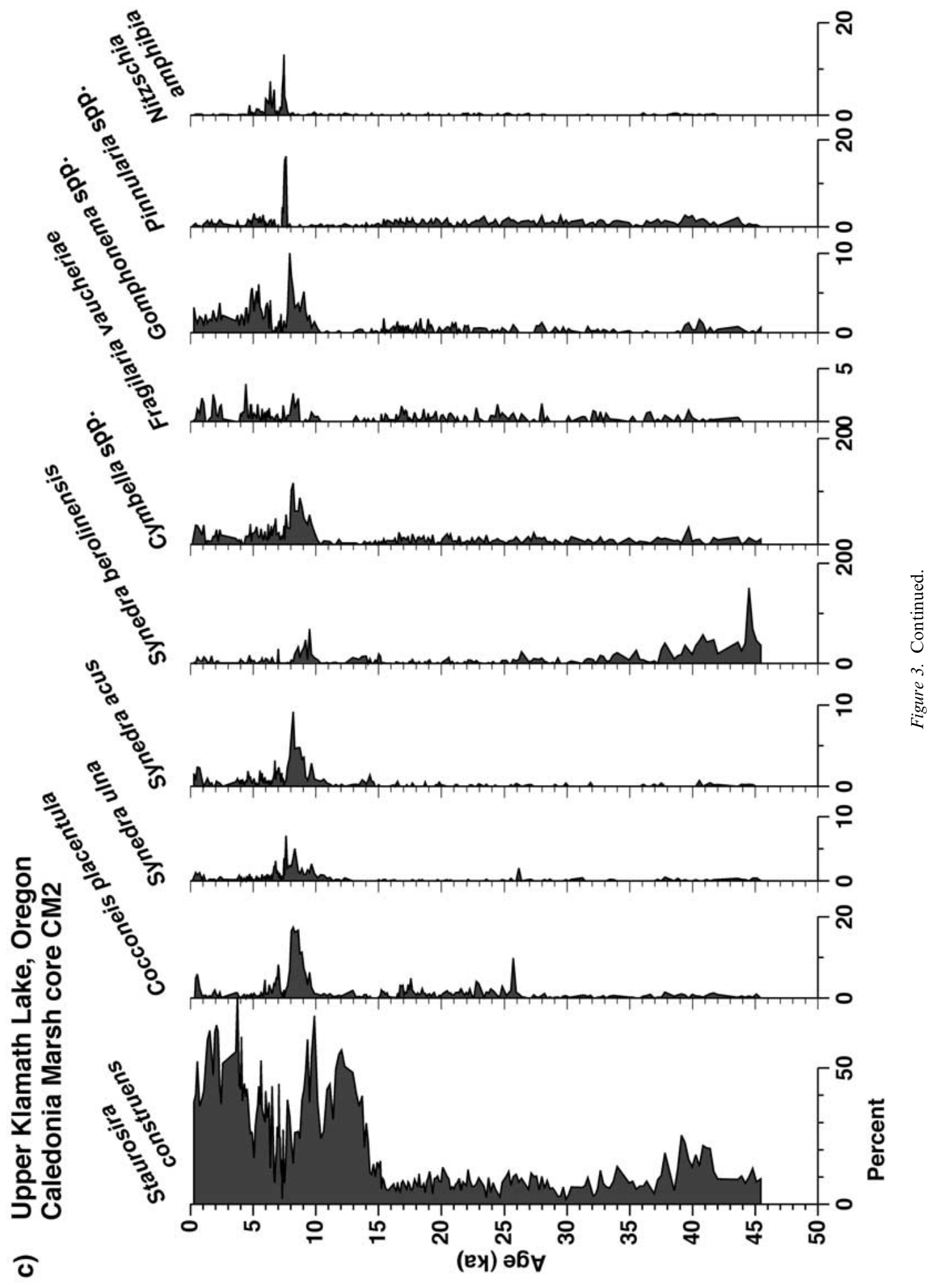




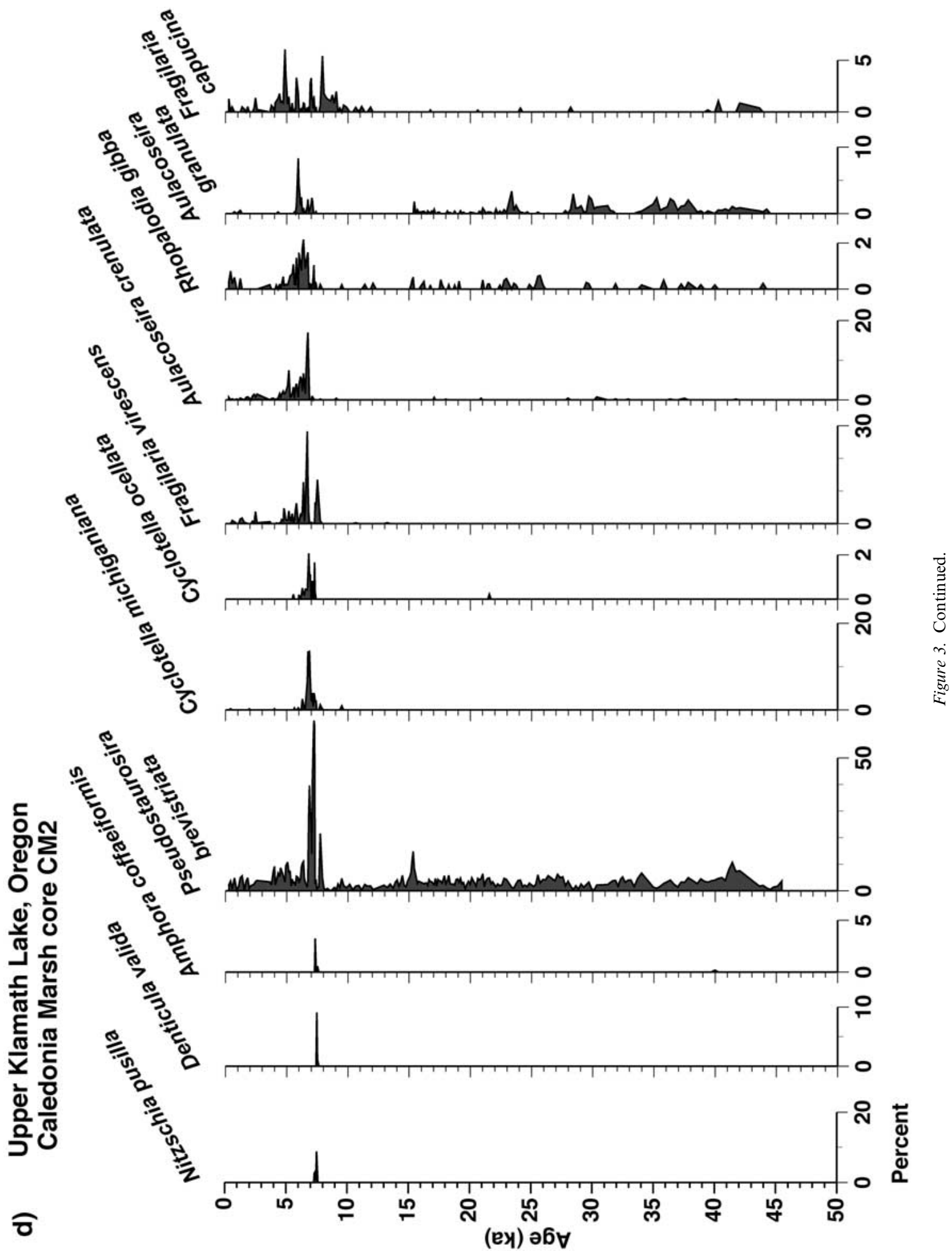




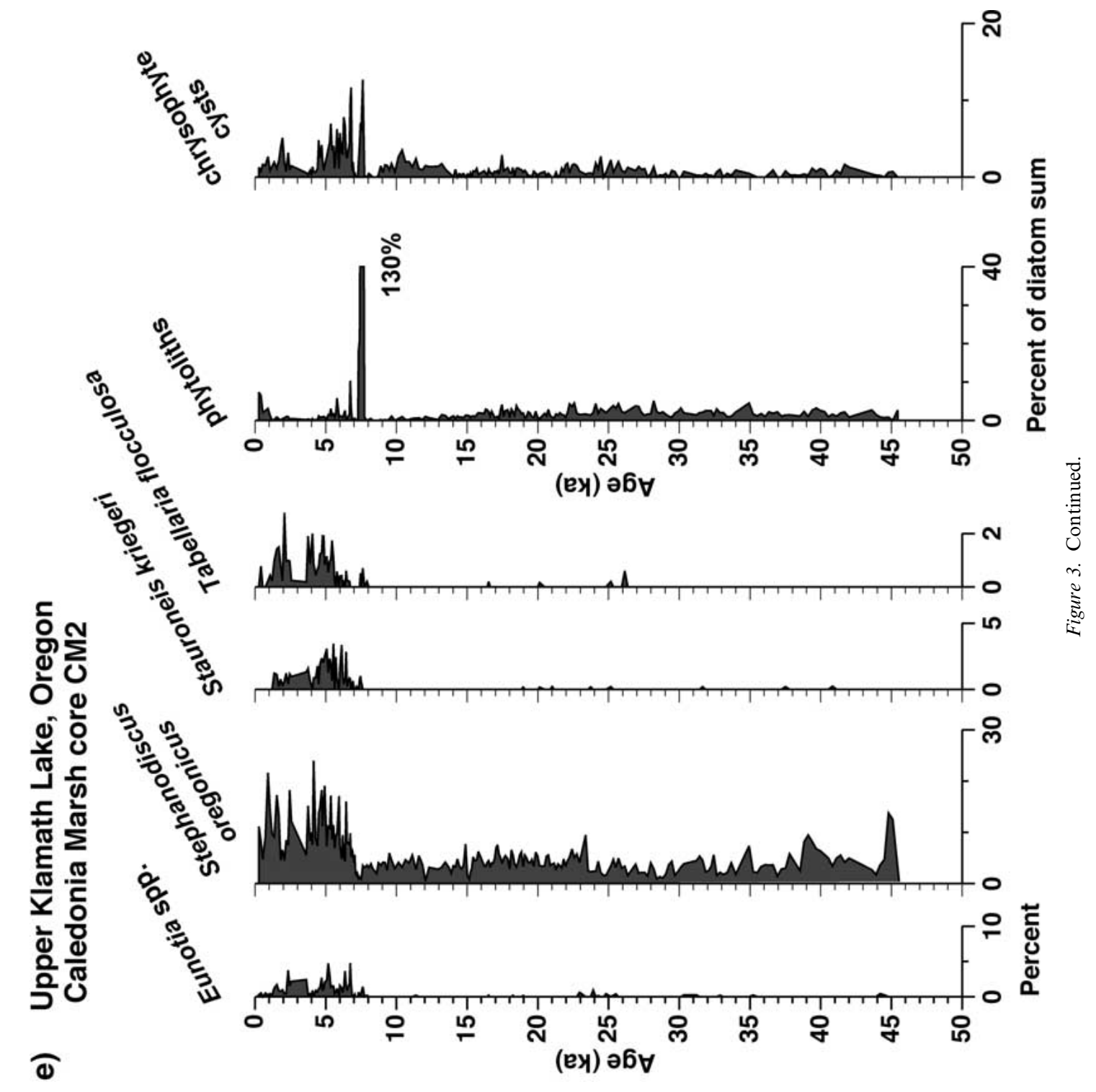


Large percentages of Stephanodiscus niagarae and lesser abundances of other, small Stephanodiscus species characterize the early lateglacial limnological record of Upper Klamath Lake (Figure 3b). Reworked Pliocene diatoms progressively decrease, but two species of the 'Fragilaria' complex (Staurosirella pinnata and Staurosira construens), become increasingly abundant over the 5-kyr interval between 15 and $10 \mathrm{ka}$ (Figure 3a, c). These bio-stratigraphic changes begin rapidly and signal an abrupt end to full glacial climates. An increase in water clarity and available nutrients probably explains the initial dominance of Stephanodiscus niagarae and other small Stephanodiscus species that bloom in the fall and spring, respectively. The shallow-water, tychoplanktic diatoms of the 'Fragilaria' complex indicate an encroaching lake margin with marsh habitats that expanded as a result of warmer and less wind-stressed conditions (reduction of wave erosion), coupled with decreased lake depth resulting from high sediment fluxes during the full glacial (Rosenbaum and Reynolds 2004 - this issue).

By the early Holocene (10-8 ka), Stephanodiscus niagarae had decreased in abundance and Staurosira construens, a loosely attached diatom living on and near rooted aquatic plants, dominated the record along with other benthic or tychoplanktic diatoms (e.g., Cocconeis placentula and species of Achnanthes, Synedra, Cymbella, and Gomphonema) indicating proximity of marsh habitats and macrophyte vegetation (Figure $3 b, c)$. The higher amount of organic matter in the core at these levels (Figure 2b) is the result of increased deposition of fragments of vascular marsh plants and sub-aquatic plants. The encroachment of marsh environments towards the open-water areas of Upper Klamath Lake could reflect lower lake levels, although the diatom assemblages do not indicate a water salinity increase that might accompany closed-lake conditions for any length of time. Of the several factors that can account for expansion and contraction of marshes relative to open water environments of shallow lakes, windinduced wave motion at the shoreline ranks high as a climatic cause. All things being equal, the amount of shoreline colonized by emergent marsh vegetation is inversely related to mean wind fetch and strength (Spence 1982). In addition, lower levels of through-flow in marsh-bound lakes means less nutrient input and consequently less phytoplankton and more transparent water with greater light penetration to favor the establishment of aquatic plants (e.g., Hutchinson 1975, p. 507).

The diatom evidence of expanded marsh and sub-aquatic vegetation from the late glacial to the mid-Holocene probably is related to the same climate changes registered in pollen profiles from small lakes in the region (West 1993; Mohr et al. 2000). A drier climate would have resulted in a reduction of winter storms, wind-generated turbulence, and wave erosion. Drier conditions also would have reduced river flow to Upper Klamath Lake resulting in seasonally lower water levels and overall more transparent conditions to promote growth of aquatic vegetation along lake shores.

The greatest extent of marsh and sub-aquatic vegetation existed between 7.5 and $5 \mathrm{ka}$ (Figure 2b). The Mazama tephra (calendar age $7.55 \mathrm{ka}$ ) covered the Upper Klamath Lake drainage basin north and east of the lake and had profound short-term effects on the limnology of Upper Klamath Lake. A large influx of phytoliths (Figure 3e) may represent terrestrial vegetation killed by the eruption, and the soil diatom, Hantzschia amphioxys (Figure 3b) could reflect erosion of denuded landscapes about the same time. Another group of species (Nitzschia amphibia, N. pusilla, Denticula valida, Amphora coffaeiformis (Figure 3c, d), and occasional individuals of Rhopalodia acuminata) indicate a brief interval of saline or alkaline-rich hydrochemical conditions (e.g., Gasse et al. 1983) at Caledonia Marsh shortly following the tephra fall. Probably redissolved labile components of the tephra and associated eruptive gases (such as $\mathrm{Cl}^{-}$ and $\mathrm{SO}_{4}{ }^{2-}$ ) were washed into marginal marsh environments around Upper Klamath Lake and thereby provided local, saline conditions to support these diatoms, as well as other species of Navicula and Nitzschia (Figure 3a). At the same time, abundant deposition and decay of marsh and other vegetation destroyed by the tephra depleted dissolved oxygen and introduced sufficient humates (Figure 2b) to the water to support several species of Pinnularia and Fragilaria virescens (Figure 3c, d), which live in neutral or lower pH environments (Gasse et al. 1983; Charles 1985).

Soon after deposition of the Mazama tephra, Stephanodiscus oregonicus became more common (Figure 3e), consistent with a decline in the areal 
extent of marshes and sub-aquatic vegetation. Pseudostaurosira brevistriata indicates that the lake maintained an alkaline $\mathrm{pH}$ for a short period, but the presence of Fragilaria virescens and subsequent appearance of Aulacoseira crenulata (Figure 3d) implies that there was a substantial input of dissolved humic material into the water to locally reduce the $\mathrm{pH}$. The brief development of Cyclotella michiganiana, $C$. ocellata, and Aulacoseira granulata (Figure 3d) suggests that there was planktic summer productivity, whereas Stephanodiscus oregonicus indicates spring production, probably associated with open-water habitats and increased seasonal nutrient availability. Nevertheless, by $5 \mathrm{ka}$, Staurosirella pinnata and Staurosira construens became the predominant diatoms indicating the persistence of shallow-water environments at the core site throughout the late Holocene. The appearance of Eunotia, Stauroneis kriegeri, and Tabellaria flocculosa (Figure 3e) during this interval indicates reduced alkalinity. This could reflect either an overall increase in precipitation and river flow through Upper Klamath Lake compared to the mid-Holocene, or simply the effect of low $\mathrm{pH}$ discharge from peaty substrates in Caledonia Marsh to Upper Klamath Lake (Snyder and Morace 1997). The abundance of chrysophyte cysts (Figure 3e) during this interval also documents reduced alkalinity and nutrient levels associated with expanded marsh environments (Sandgren 1988).

By the time of Euro-American discovery of Upper Klamath Lake, Stephanodiscus oregonicus and Aulacoseira ambigua had become the principal planktic diatoms, but their abundance at the Caledonia Marsh core site was low compared to shallow-water species of the 'Fragilaria' complex. Road berm construction (A.D. 1916) that separated Caledonia Marsh from the open water of Upper Klamath Lake compromised the integrity of the uppermost part of the record. Consequently, selected diatom profiles of the short core from Howard Bay document the latest Holocene paleolimnology of this part of Upper Klamath Lake.

\section{Stratigraphy and interpretation of core HB}

The calendar year chronology for the Howard Bay core (Figure 4) was developed from radiocarbon

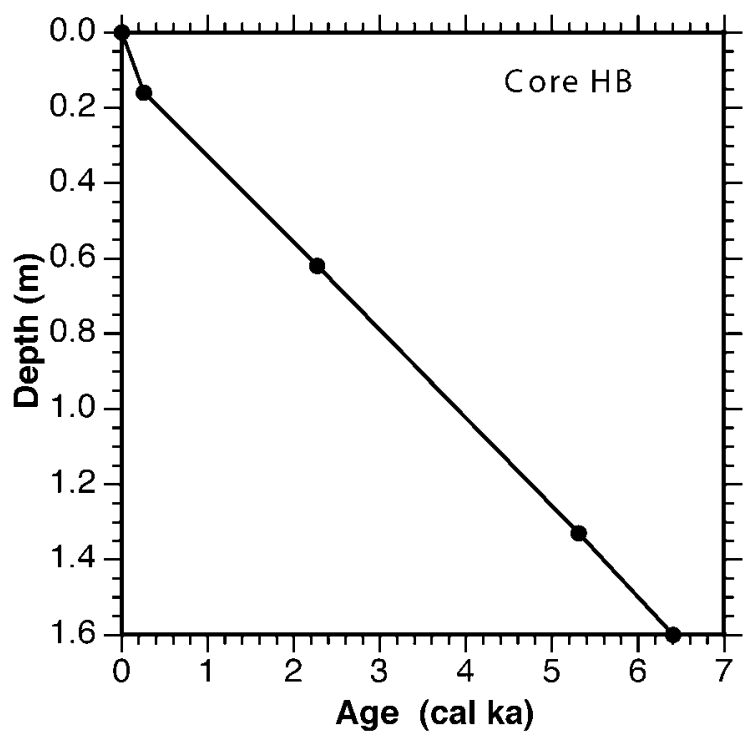

Figure 4. Age (in cal ka) versus depth in core for core $\mathrm{HB}$ (Colman et al. 2004a - this issue). Data points are radiocarbon ages or diatom correlations to ${ }^{210} \mathrm{~Pb}$ age estimates in other cores.

ages and a diatom correlation to ${ }^{210} \mathrm{~Pb}$-dated cores (Colman et al. 2004a - this issue). The Howard Bay core site is located just north of Caledonia Marsh in shallow but open water (Colman et al. 2004b - this issue, their Figure 2). Marsh vegetation historically has not grown in the bay (Bortleson and Fretwell 1993), perhaps because of its steep and exposed shores. Nevertheless, proximity to Caledonia Marsh and generally turbulent water conditions ensure that tychoplanktic diatoms of the 'Fragilaria' complex dominate the stratigraphy at this site (Figure 5a). The base of the HB core, dated to about $6 \mathrm{ka}$, contains minor occurrences of Aulacoseira granulata, Synedra berolinensis, Cocconeis placentula, and other attached diatoms. Planktic diatoms, Stephanodiscus niagarae and $S$. oregonicus, are also comparatively common in this part of the core (Figure 5b).

These diatom assemblages correlate to the Caledonia Marsh core at approximately coeval levels. For example, Aulacoseira granulata also peaks in CM2 at $6 \mathrm{ka}$ (Figure 3d) and suggestive correlations exist with Synedra berolinensis, Cocconeis placentula, and Stephanodiscus niagarae (Figure 3b, c). A subsequent small peak of Aulacoseira ambigua in core $\mathrm{HB}$ at 6-5 ka (Figure 5b) also registers in core $\mathrm{CM} 2$ at $5 \mathrm{ka}$ 


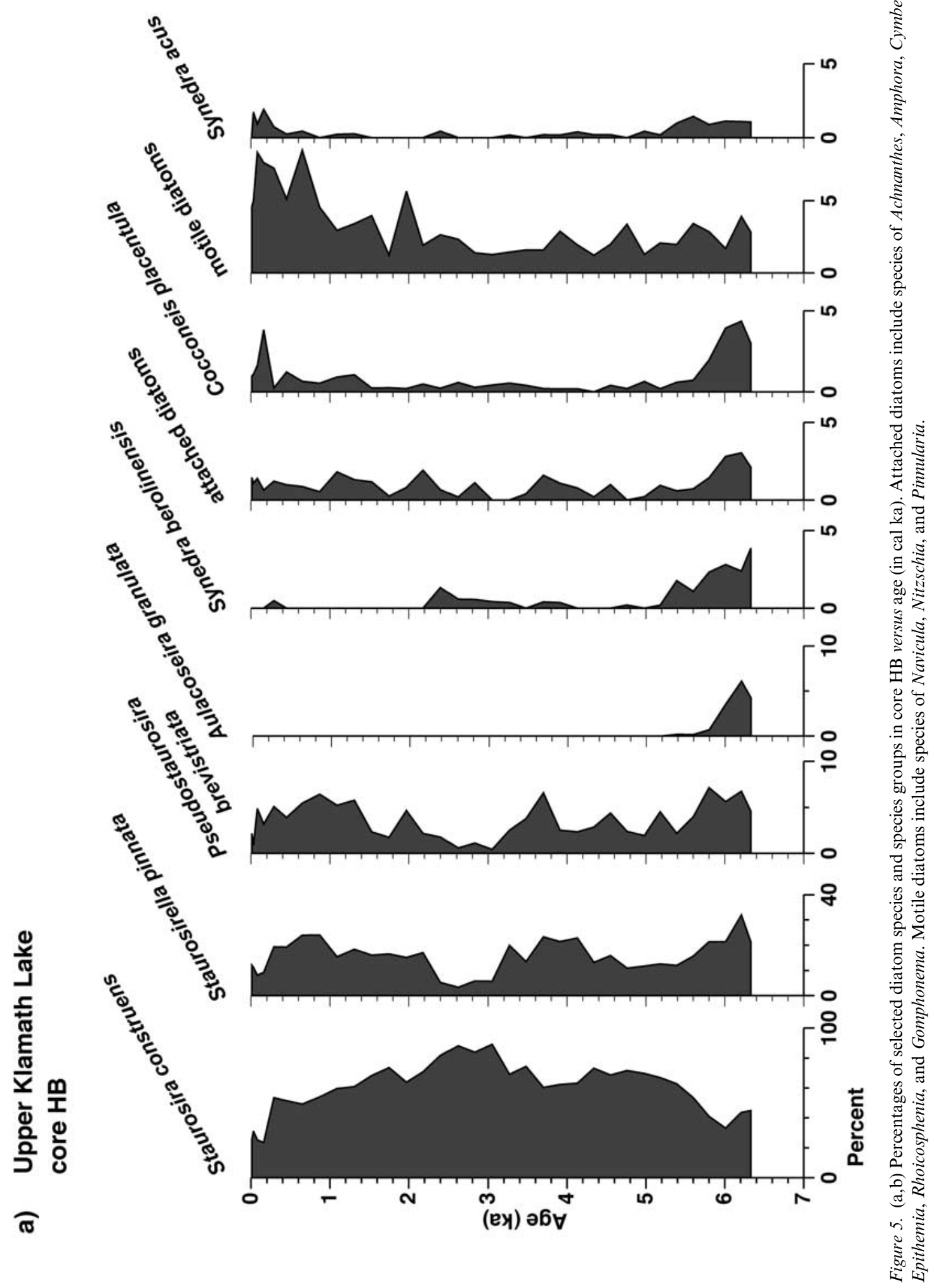




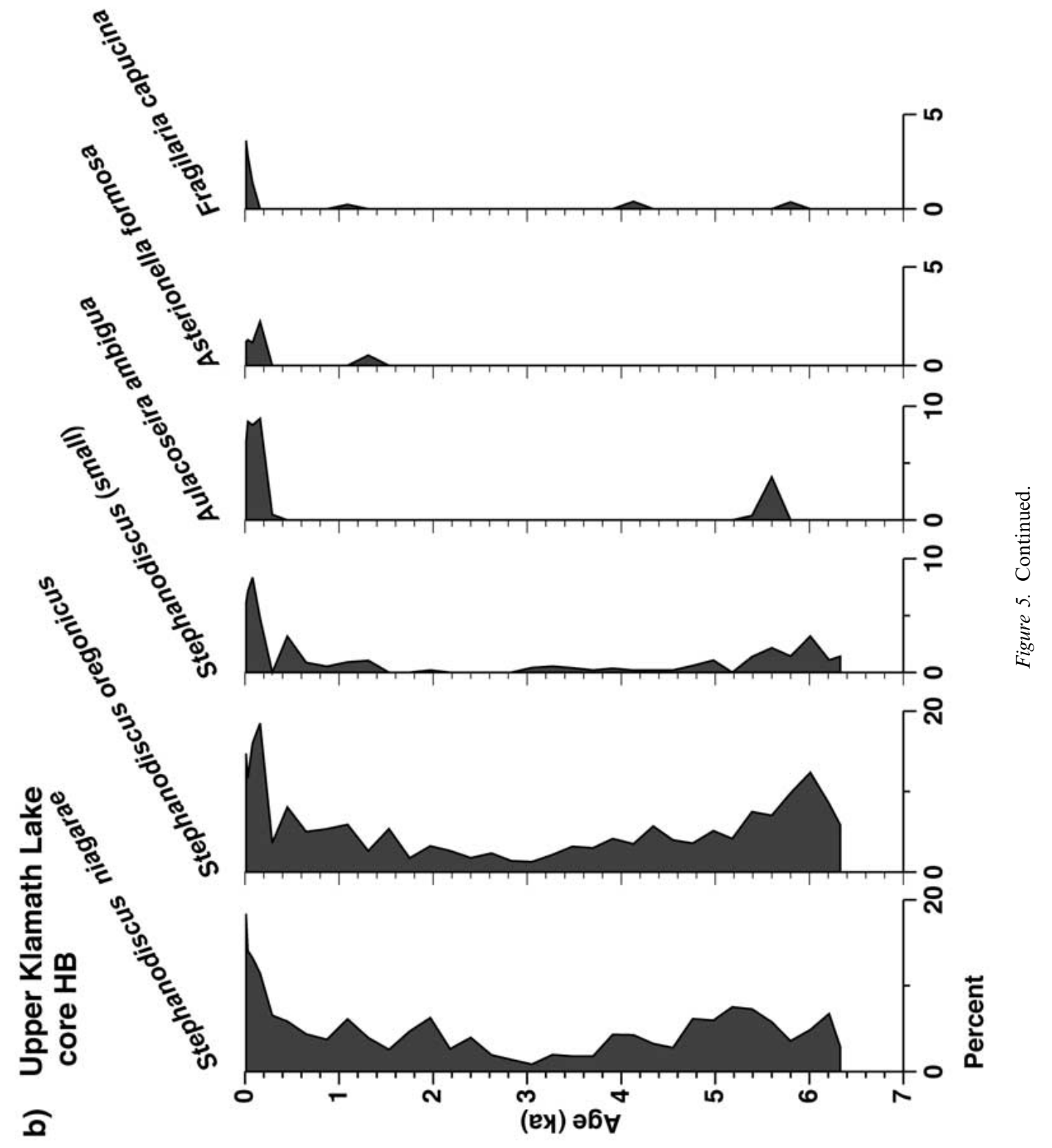


(Figure 3a). The fact that the age distributions of these taxa in different cores are not exactly coeval probably reflects different age model estimates for the available independent chronological controls for each core.

According to the distribution of planktic diatoms in core $\mathrm{HB}$, somewhat more open-water conditions existed at $6-5 \mathrm{ka}$ and again over the past 300 years. Otherwise, the late Holocene was characterized by shallow-water marsh taxa that accumulated as a nearly pure diatomite on the bottom of Howard Bay. These late Holocene changes were minor, however, compared to earlier limnological changes registered in core CM2. Nevertheless, the open-water diatoms do document sensible climate changes that probably relate to increased precipitation. The most recent change, beginning about 260 years ago, may correlate with tree-ring evidence from eastern Oregon that shows generally increased moisture since A.D. 1750 until the late 19th century (Keen 1937). The strong increase of small Stephanodiscus species ( $S$. hantzschii and $S$. parvus) during the last century of the record may record eutrophication from marsh drainage and agriculture in the southern part of Upper Klamath Lake.

\section{Stratigraphy and interpretation of core K1}

Both the Caledonia Marsh (CM2) and Howard Bay (HB) core sites are located in a lake margin environment near the southern end of Upper Klamath Lake (Colman et al. 2004b - this issue, their Figure 2). Core K1 came from the northern end of Upper Klamath Lake, almost $16 \mathrm{~km}$ from Caledonia Marsh and Howard Bay, in open water near the lake center. Diatom analysis of this core provides a means to evaluate the areal extent of paleolimnological changes inferred from the Caledonia Marsh and Howard Bay sites at the southern end of Upper Klamath Lake and to assess the magnitude of lake-marsh interactions from the perspective of a limnetic environment with a somewhat greater representation of planktic diatoms.

Core K1 extends back to about $14.5 \mathrm{ka}$ according to the chronology constructed from corrected radiocarbon ages and the position of several tephra units (Colman et al. 2004a - this issue). The age model (Figure 6) indicates comparatively slower deposition rates between 14.5 and $7 \mathrm{ka}$, and faster rates there-

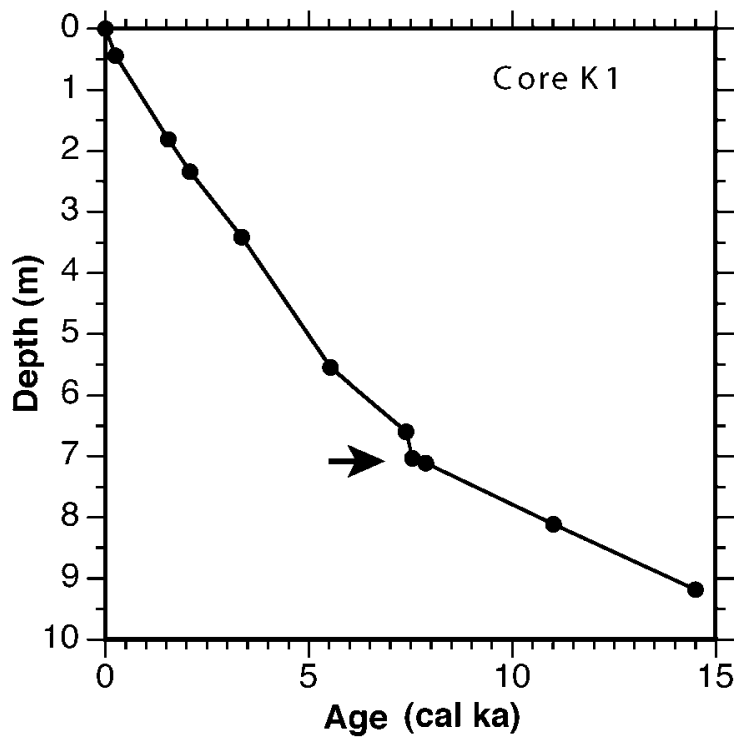

Figure 6. Age (in cal ka) versus depth in core for core K1 (Colman et al. 2004a - this issue). Arrowhead marks location of Mazama tephra datum point; other points are radiocarbon or ${ }^{210} \mathrm{~Pb}$ ages.

after. Aulacoseira subarctica and A. ambigua characterized the beginning of the record (Figure 7a) and correlate with high percentages of these species in core CM2 (Figure 3a). Percentages of Aulacoseira islandica, however, are low at the base of core K1 suggesting that this core did not extend to levels of CM2 $(15.5 \mathrm{ka})$ where this species is very abundant $(>20 \%$, Figure $3 \mathrm{a})$. By about $13.8 \mathrm{ka}$, the spring and fall planktic diatoms, small Stephanodiscus spp. and $S$. niagarae, respectively, dominate the K1 record, with increasing numbers of Aulacoseira islandica until about $8 \mathrm{ka}$. The character of the abundance profiles of these diatom species in core $\mathrm{K} 1$ is similar to those in core CM2, implying that Upper Klamath Lake was large and environmentally homogeneous during the late glacial and early Holocene periods. The abundance of heavy mineral fragments and, to a lesser extent, reworked Pliocene diatoms, especially during the late glacial period (Figure 7a, b), probably documents the energetic character of winds affecting the lake at that time.

As at Caledonia Marsh, Staurosira construens became very common in the early Holocene of core $\mathrm{K} 1$, indicating the expansion of marsh environments that ultimately imply less discharge into, and flow through, Upper Klamath Lake. The occurrence of Cyclotella michiganiana, a planktic diatom 


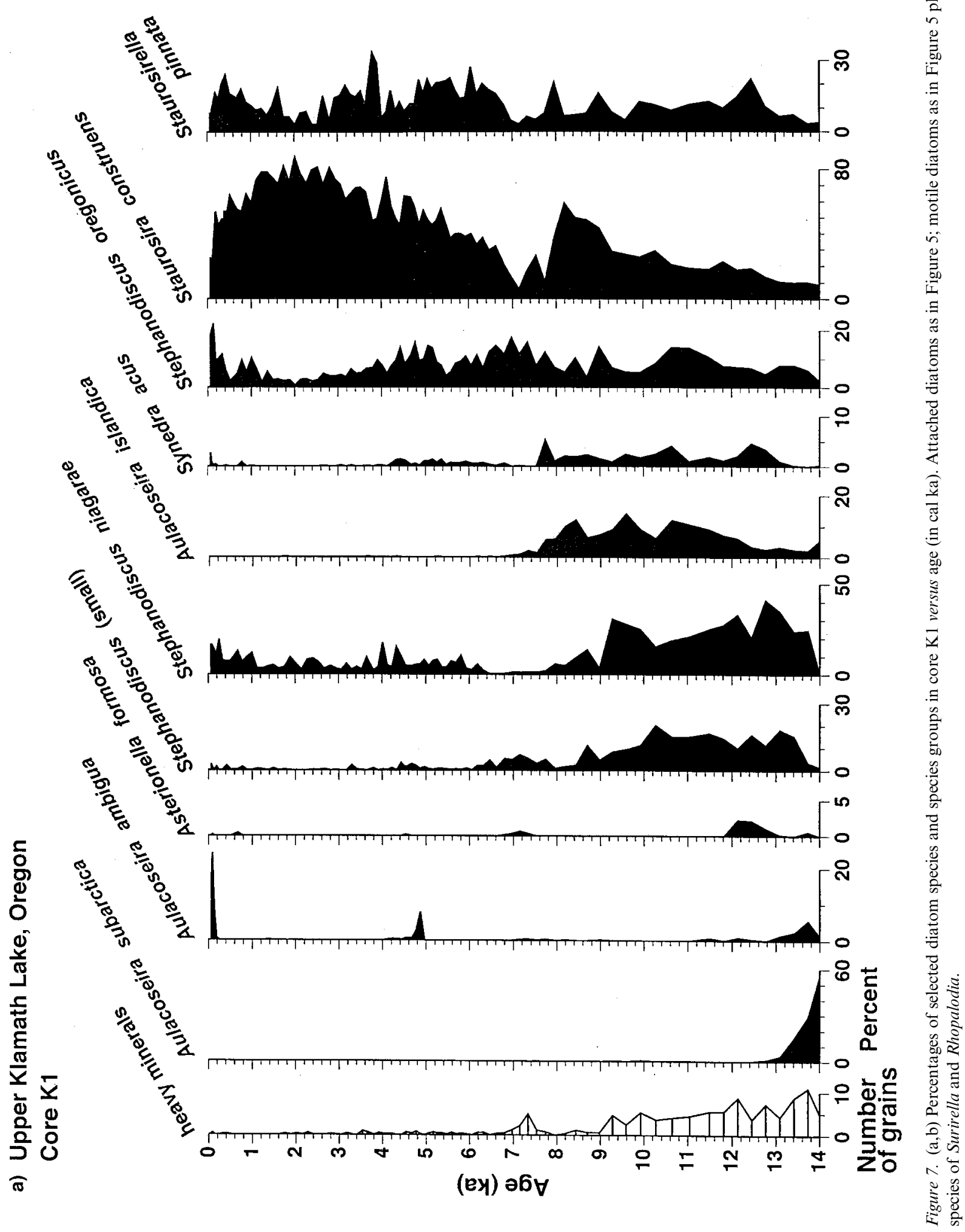




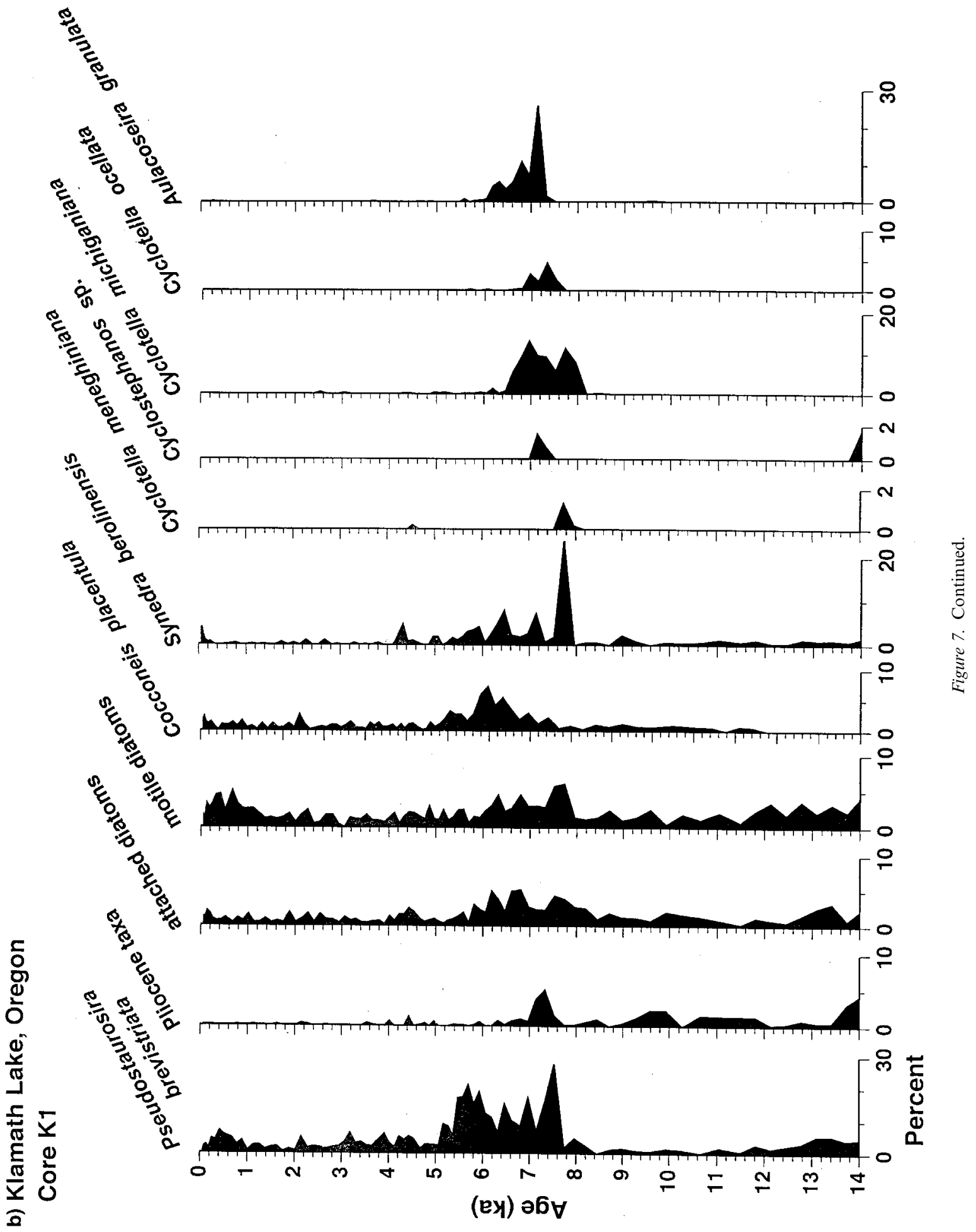


whose salinity optimum is between 1 and $2 \mathrm{~g} / \mathrm{l}$ (Fritz et al. 1993) indicates that by $8 \mathrm{ka}$ openwater habitats of Upper Klamath Lake had also become slightly more saline and alkaline. The partial replacement of Staurosira construens by Pseudostaurosira brevistriata at that time and until $5 \mathrm{ka}$ also suggests that the water of Upper Klamath Lake became somewhat more concentrated because $P$. brevistriata has a higher salinity optimum than $S$. construens (Cumming and Smol 1993). By the time of the eruption of the Mazama tephra $(7.55 \mathrm{ka})$, attached and motile benthic diatoms, and Pseudostaurosira brevistriata became increasingly common, indicating the most extensive phase of marsh development along the margins of the lake.

The direct impact of the Mazama tephra on the open-water limnology of Upper Klamath Lake was registered by a peak of Synedra berolinensis and low percentages of Cyclotella meneghiniana at that level (Figure 7b). This assemblage testifies to somewhat increased limnetic productivity, $\mathrm{pH}$, and salinity as did the diatoms from the Caledonia Marsh record. Salinity changes, however, were not so large as those recorded by the coeval Caledonia Marsh diatoms, probably because of greater water circulation and shorter water residence time in the open part of Upper Klamath Lake. Nevertheless, the limnological changes can reasonably be ascribed to the release of labile components of the tephra at both sites.

For the next millennium following the Mazama tephra, the planktic diatoms Cyclotella ocellata, indicative of alkaline water (Gasse 1986), $C$. michiganiana, and Aulacoseira granulata predominated. As expected, these diatoms are also seen in core CM2 above the Mazama tephra, but in somewhat lower percentages that reflect the marshdominated environment at that site (Figure $3 \mathrm{~d}$ ). It is probable that the persistence of planktic diatoms adapted to alkaline, mildly saline, and silica-rich water after the Mazama eruption reflects the continued weathering of labile ash components in the drainages north of Upper Klamath Lake, which reach to the slopes of Mount Mazama (Crater Lake). On the other hand, the continued abundance of Cocconeis placentula and other diatoms associated with marsh environments probably indicate control by warm and dry mid-Holocene climates of the hydrological budget of Upper Klamath Lake. The small peak of reworked
Pliocene diatoms following the Mazama eruption (Figure 7b) could document seasonally strong precipitation and flashy runoff east of Upper Klamath Lake in the Sprague River drainage. Stephanodiscus oregonicus continued as the principal planktic diatom in the lake as the impact of the Mazama tephra diminished and the climate shifted to less stormy and variable conditions of precipitation and discharge.

By 4 ka, Staurosira construens returned to dominate the diatom assemblages of Upper Klamath Lake, whereas diatoms associated with rooted aquatic vegetation (e.g., Cocconeis placentula) became less common, and planktic diatom production diminished. Pollen records from the Klamath Mountains in California show vegetation consistent with cool and moist climates for this part of the late Holocene (Mohr et al. 2000); it is reasonable that at Upper Klamath Lake marsh habitats became stable under climatic conditions that ensured ample hydrological discharge to the system. Climatic regimes of strong winds to maintain open water environments against encroaching marshes, and to supply turbulence and nutrients to support planktic diatoms, apparently did not predominate during much of the late Holocene at Upper Klamath Lake.

The variable climate of the latest Holocene, perhaps associated with changes elsewhere known as the Medieval Warm Period and the Little Ice Age, may account for the revival of planktic diatom production during the past millennium. The most pronounced change occurs near the top of core K1 with a sharp increase in Aulacoseira ambigua (Figure 7a), but the uppermost $8 \mathrm{~cm}$ of sediments in this section were not recovered (Colman et al. 2004a - this issue). However, the Howard Bay (HB) core has a clear expression of the increase in planktic species (Stephanodiscus niagarae, S. oregonicus, small Stephanodiscus species, and Aulacoseira ambigua) about 200 years ago that end the predominance of stable, marsh-dominated aquatic communities in Upper Klamath Lake.

\section{Discussion}

The diatom stratigraphy of both long and short cores from Upper Klamath Lake shows clearly correlative changes involving distinctive diatom 
assemblages and species distributions over large areas of the lake basin. Despite tectonic activity (Colman et al. 2000) the sediment record in the basin reliably and consistently records paleolimnological changes resulting from climate changes and tephra deposition. Interestingly, the comparative record at Tule Lake (Bradbury 1991), in the same hydrographic basin but $60 \mathrm{~km}$ southeast of Upper Klamath Lake, shows only the most dramatic paleolimnological changes recorded in Upper Klamath Lake. At Tule Lake, as at Upper Klamath Lake, abundant, reworked Pliocene diatoms characterize full glacial intervals, especially between 30 and $15 \mathrm{ka}$. This correlation testifies to pervasive effects of cold, dry, and windy environments in northern California and southern Oregon during the full glacial. The fact that most of the Pliocene diatomceous outcrops lie to the east and north of the Upper Klamath and Tule Lake basins implicates northeasterly winds to deposit these characteristic diatoms in the respective lake basins. Such persistent winds probably relate to the glacial anticyclone that developed around the Laurentide/Cordilleran ice sheets (Kutzbach and Guetter 1986), and was responsible for the cold, dry climate over much of the Pacific Northwest (Barnosky et al. 1987).

After the full glacial, the Tule Lake and Upper Klamath Lake records differ. Although the Tule Lake core chronology is not well constrained in this interval, both records show increases in 'Fragilaria' after about $15 \mathrm{ka}$ indicating a reduction of wind stress and expansion of fringing marsh vegetation around both basins. However, in Tule Lake 'Fragilaria' was accompanied by large numbers of Aulacoseira ambigua, whereas in Upper Klamath Lake, Stephanodiscus niagarae was the predominant post-glacial diatom associated with the 'Fragilaria' species, at least until $10 \mathrm{ka}$. The difference in planktic diatoms between the two basins may reflect morphometric differences between the basins. Tule Lake (before drainage) was a largely separate, more exposed basin than Upper Klamath Lake. Large fetch and high winds may have provided comparatively larger expanses of open water to support planktic diatoms, particularly in the summer (when Aulacoseira ambigua blooms) after spring hydrological input from the Lost River.

The distribution of Aulacoseira ambigua in the long diatom record from Upper Klamath Lake
(CM2) provides an opportunity to compare climate-forced paleolimnological changes at Upper Klamath Lake $\left(42^{\circ} \mathrm{N}\right)$ and at Owens Lake $\left(36.5^{\circ} \mathrm{N}\right)$ during OIS 3. As suggested earlier, the full glacial period (OIS 2) at Upper Klamath Lake was cold, relatively dry, and windy, probably as a result of the glacial anticyclone that formed above the Laurentide/Cordilleran ice sheets. At that time, the mass of cold, Arctic air that reached at least as far south as Upper Klamath Lake, forced the Aleutian Low into a more southerly position. Storm tracks impacting the California coast from the southern side of the Aleutian Low provided abundant precipitation to the Sierra Nevada whose eastern drainages fed Owens Lake. Consequently, for most of OIS 2, when climate at Upper Klamath Lake was cold and dry, Owens Lake was full, fresh, and overflowing in a climate that was cooler and moister than today (Bradbury and Forester 2002).

One of the recurrent characteristics of climate during the 20 millennia preceding the full glacial (OIS 3) was strong, multi-millennial-scale climate variability (e.g., Heinrich 1988; Kennett and Venz 1995). During this stage, cold-warm and(or) dry-wet climate modes alternated, and the alternations of Aulacoseira ambigua in both Owens Lake (Bradbury and Forester 2002) and at Upper Klamath Lake (Figure 3a) appear to document these climate changes. At Owens Lake, Aulacoseira ambigua, which blooms in the summer, indicates a climate with such abundant winter precipitation that runoff from the Sierra Nevada maintained fresh and nutrient-rich conditions all summer, thereby providing appropriate habitats for this diatom. At Upper Klamath Lake, Aulacoseira ambigua represents similar wet climate conditions that probably reflect abundant moisture from winter storms and perhaps windy spring and summer environments that provide turbulence for this diatom.

According to the available chronologies, the abundances of Aulacoseira ambigua are approximately out-of-phase between Owens Lake and Upper Klamath Lake (Figure 8). This suggests, within the reliability of the respective chronologies, that when Owens Lake was receiving abundant moisture from westerly storm tracks, Upper Klamath Lake, almost $6^{\circ}$ farther north, was cold, under the influence of an Arctic air mass, and relatively dry and windy - an environment that 

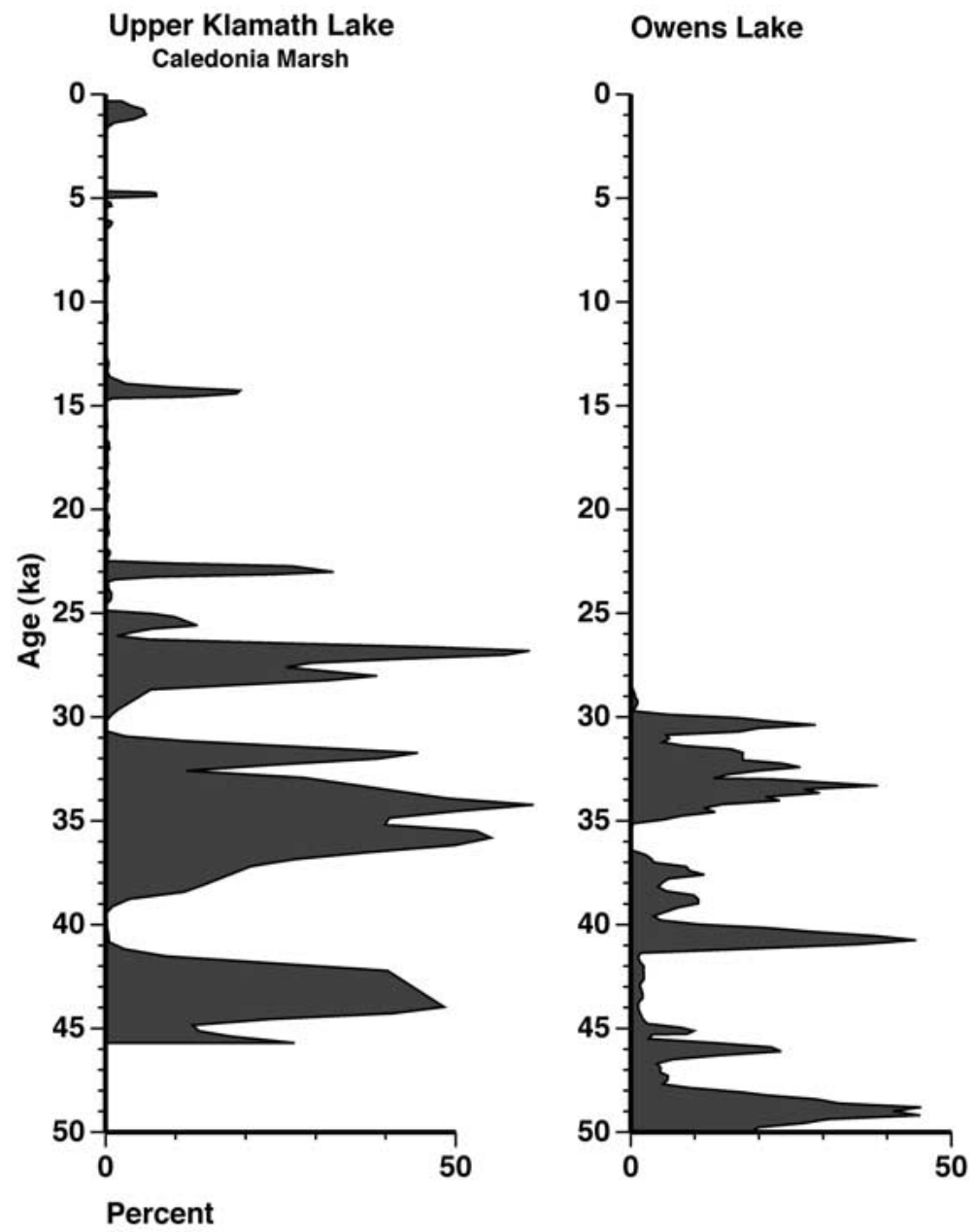

Figure 8. Percentages of Aulacoseira ambigua (three-point smoothing) from Upper Klamath Lake (Caledonia Marsh), Oregon and from Owens Lake, California plotted according to their respective age models. Owens Lake data are from Bradbury and Forester (2002).

did not support high numbers of Aulacoseira ambigua, but rather $A$. subarctica and $A$. islandica, another cold-season Aulacoseira species (Figure 3a). In addition to documenting switching of major climate modes and their spatial characteristics during the mid-Wisconsin, the diatom profiles from both Owens and Upper Klamath Lakes indicate that such changes occurred rapidly, in many cases on the order of centuries or less.

\section{Conclusions}

The diatom stratigraphies from several cores collected at Upper Klamath Lake, Oregon, document millennial- and centennial-scale climate changes that affected the limnology of this lake. Even though the basin shape, depth, and extent have been modified by tectonism, correlations between distinctive diatom assemblages are convincing and probably signal coeval changes in the lake.

The longest record, from Caledonia Marsh, illustrates major climate shifts. The part of this record spanning OIS 3 shows that the climate generally was cold and windy. Pliocene diatoms were redeposited from nearby outcrops and cold temperate diatoms characterized the lake. Arctic air probably resided near the latitude of Upper Klamath Lake $\left(42^{\circ} \mathrm{N}\right)$ for much of the year. However, three short, abrupt intervals between 45 and $25 \mathrm{ka}$ were warmer and wetter than the mean for OIS 3, probably because the Aleutian Low 
shifted to the north, allowing moisture to reach the region under seasonally warm climates.

During the full glacial (25-15 ka) benthic diatoms, reworked Pliocene diatoms, and cold-season, northern temperate planktic diatoms dominated the record. Abruptly, at $15 \mathrm{ka}$, Upper Klamath Lake became limnologically similar to its late Holocene state prior to Euro-American settlement. Wind stress declined and temperatures rose. Diatoms from fringing marshes became abundant to document the expansion of shallow water habitats. In the mid-Holocene, lake levels appear marginally lower, at least seasonally, and hydrological discharge to the system may have been reduced. The deposition of the Mazama tephra had a significant impact on the lake that may have lasted for a millennium, even though ash deposition directly on the lake was minimal. Today, the impacts of Euro-American settlement on Upper Klamath Lake have greatly reduced the abundance and diversity of diatoms, particularly the planktic species that bloom during the summer months. Cyanobacteria (mostly Aphanizomenon flos-aquae) now dominate this lacustrine ecosystem because of the extensive nutrient fluxes from marsh drainage and subsequent agriculture practices (Bradbury et al. 2004 - this issue).

\section{Acknowledgements}

We thank J. Bratton and K. Moser for helpful reviews of earlier versions of this paper. This project was supported by the Global Change and Climate History (now Earth Surface Dynamics) Program of the US Geological Survey.

\section{References}

Adam D.P., Bradbury J.P., Dean W.E. and Sarna-Wojcicki A.M. 1995. US Geological Survey Open-File Report 95-34, 92 pp.

Barnosky C.W., Anderson P.M. and Bartlein P.J. 1987. The northwestern US during deglaciation; vegetational history and paleoclimatic implications. In: Ruddiman W.F. and Wright H.E. Jr. (eds), North America and the Adjacent Oceans During the Last Deglaciation, v. K-3, The Geology of North America. Geological Society of America, Boulder, Colorado, pp. 289-321.

Battarbee R.B. 1973. A new method for the estimation of absolute microfossil numbers, with reference especially to diatoms. Limnol. Oceanogr. 18: 647-653.

Bortleson G.C. and Fretwell M.O. 1993. A review of possible causes of nutrient enrichment and decline of endangered sucker populations in Upper Klamath Lake, Oregon. US Geological Survey Water Resources Investigations Report 93-4087, 24 pp.

Bradbury J.P. 1991. The late Cenozoic diatom stratigraphy of Tule Lake, Siskiyou County, California. J. Paleolim. 6: 205-255.

Bradbury J.P. and Forester R.M. 2002. Environment and paleolimnology of Owens Lake, California: a record of climate and hydrology for the past 50,000 years. In: Hershler R., Madsen D.B. and Currey D.R. (eds), Great Basin Aquatic System History. Smithsonian Contributions to the Earth Sciences. No. 33, pp. 145-173.

Bradbury J.P., Colman S.M. and Reynolds R.L. 2004. The history of recent limnologic changes and human impact on Upper Klamath Lake, Oregon. J. Paleolim. 31: 151-165 (this issue).

Charles D.F. 1985. Relationships between surface sediment diatom assemblages and lakewater characteristics in Adirondak lakes. Ecology 66: 994-1011.

Colman S.M., Bradbury J.P., McGeehin J.P., Holmes C.W., Edginton D. and Sarna-Wojcicki A.M. 2004a. Chronology of sediment deposition in Upper Klamath Lake, Oregon. J. Paleolim. 31: 139-149 (this issue).

Colman S.M., Bradbury J.P. and Rosenbaum J.G. 2004b. Paleolimnology and paleoclimate studies in Upper Klamath Lake, Oregon. J. Paleolim. 31: 129-138 (this issue).

Colman S.M., Rosenbaum J.G., Reynolds R.L. and SarnaWojcicki A.M. 2000. Post-Mazama (7 KA) faulting beneath Upper Klamath Lake, Oregon. Bull. Seismol. Soc. Am. 90: 243-247.

Cumming B.F. and Smol J.P. 1993. Development of diatombased salinity models for paleoclimatic research from lakes in British Columbia (Canada). Hydrobiologia 269/270: 179-196.

Dean W.E. 1974. Determination of carbonate and organic matter in calcareous sediments and sedimentary rocks by loss on ignition: Comparison with other methods. J. Sediment. Petrol. 44: 242-248.

Dean W.E. 1993. Physical properties, mineralogy, and geochemistry of varved sediments from Elk Lake, Minnesota. In: Bradbury J.P. and Dean W.E. (eds), Elk Lake, Minnesota: Evidence for Rapid Climate Change in the North-Central United States, Geological Society of America, Special Paper 276, pp. 135-157.

Dean W.E. 1996. Geochemistry of sediments from Tule Lake, California. US Geological Survey Open-File Report 96-257, $36 \mathrm{pp}$.

Dean W.E. and Schwalb A. 2002. The lacustrine carbon cycle as illuminated by the waters and sediments of two hydrologically distinct hardwater lakes in northwestern Minnesota. J. Sed. Res. 72: 416-431.

Engleman E.E., Jackson L.L., Norton D.R. and Fischer A.G. 1985. Determination of carbonate carbon in geological materials by coulometric titration. Chem. Geol. 53: $125-128$

Fritz S.C., Juggins S. and Battarbee R.W. 1993. Diatom assemblages and ionic characterization of lakes of the northern Great Plains. North America: A tool for reconstructing past salinity and climate fluctuations. Can. J. Fish. Aquat. Sci. 50: 1844-1856. 
Gasse F. 1986. East African diatoms - taxonomy, ecological distribution. Bibliotheca Diatomol. 11: 201

Gasse F., Talling J.F. and Kilham P. 1983. Diatom assemblages in East Africa: classification, distribution, and ecology. Rev. Hydrobiol. Trop. 16: 3-34.

Heinrich H. 1988. Origin and consequences of cyclic ice rafting in the northeast Atlantic Ocean during the past 130000 years. Quater. Res. 29: 142-152.

Hutchinson G.E. 1975. A Treatise on Limnology, v. III, Wiley, New York, 660 pp.

Jewson D.E. 1992. Size reduction, reproductive strategy and the life cycle of a centric diatom. Phil. Trans. R. Soc. London, Ser. B 336: 191-213.

Keen F.P. 1937. Climate cycles in eastern Oregon as indicated by tree rings. Monthly Weather Rev. 65: 175-188.

Kennett J.P. and Venz K. 1995. Late Quaternary climatically related planktonic foraminiferal assemblage changes: Hole 893A, Santa Barbara Basin, California. In: Kennett J.P., Baldauf J.G. and Lyle M. (eds), Proceedings of the Ocean Drilling Program, Scientific Results, v. 146(2), pp. 281-293.

Kilham P., Kilham S.S. and Hecky R.E. 1986. Hypothesized resource relationships among African planktonic diatoms. Limnol. Oceanogr. 31: 1169-1181.

Kutzbach J.E. and Guetter P.J. 1986. The influence of changing orbital parameters and surface boundary conditions on climate simulations for the past 18000 years. J. Atm. Sci. 43: 1726-1759.

Lichte F.E., Golightly D.W. and Lamothe P.J. 1987. Inductively coupled plasma-atomic emission spectrometry. In: Baedecker P.A. (ed.), Methods for Geochemical Analysis, US Geological Surver Bulletin, 1770, pp. B1-B10.

Mohr J.A., Whitlock C. and Skinner C.N. 2000. Postglacial vegetation and fire history, eastern Klamath Mountains, California, USA. The Holocene 10: 587-601.
Reynolds R.L., Rosenbaum J.G., Rapp J., Kerwin M.W., Bradbury J.P., Colman S.M. and Adam D.P. 2004. Record of Late Pleistocene glaciation and deglaciation in the southern Cascade Range: I. Petrological evidence from lacustrine sediment in Upper Klamath Lake, southern Oregon. J. Paleolim. 31: 217-233 (this issue).

Rosenbaum J.G. and Reynolds R.L. 2004. Record of Late Pleistocene glaciation and deglaciation in the southern Cascade Range: II. Flux of glacial flour in a sediment core from Upper Klamath Lake. J. Paleolim. 31: 235-252 (this issue).

Sandgren C.D. 1988. The ecology of chrysophyte flagellates: Their growth and perennation strategies as freshwater phytoplankton. In: Sandgren C.D. (ed.), Growth and Reproductive Strategies of Freshwater Phytoplankton, Cambridge University Press, London, pp. 9-104.

Snyder D.T. and Morace J.L. 1997. Nitrogen and phosphorus loading from drained wetlands adjacent to Upper Klamath and Agency Lakes, Oregon. US Geological Survey WaterResources Investigations Report 97-4059, 67 pp.

Spence D.H.N. 1982. The zonation of plants in freshwater lakes. In: MacFayden A. and Ford E.D. (eds), Advances in Ecological Research, v. 12: Academic Press, New York, pp. 37-125.

Stoermer E.F., Hakansson H. and Theriot E.C. 1987. Cyclostephanos species newly reported from North America: C. tholifornis sp. nov. and C. costatilimbus comb. nov. Br. Phycol. J. 22: 349-358.

West G.J. 1993. The late Pleistocene - Holocene pollen record and prehistory of California's north Coast Ranges. In: White G.P.M., Hildebrandt W.R. and M.E., B. (eds), There Grows a Green Tree: Papers in Honor of David A. Fredrickson, Center for Archaeological Research at Davis, Publication 11, Davis, California, pp. 219-236. 